\title{
Developing Civil Servants' Commitment to Share Knowledge and Implement Cost Reduction Policy: The Perspective of Malaysian Public Sector
}

\author{
Mohamad Hisyam Selamat (Corresponding author) \\ Faculty of Business, Accounting and Management, SEGi University \\ Level 10 SEGi Tower, 47810 Petaling Jaya, Malaysia \\ Tel: 603-6145-5888Ｅ-mail: mohdhisyam@segi.edy.my \\ Haliza Mazlin Abdul Halim \\ Faculty of Business, Accounting and Management, SEGi University \\ Level 10 SEGi Tower, 47810 Petaling Jaya, Malaysia \\ Tel: 603-6145-5888Ｅ-mail: haliza@segi.edu.my
}

\author{
Foo Kok Soon \\ Institute of Graduate Studies, SEGi University \\ 47810 Petaling Jaya, Malaysia
}

Tel: 603-6145-1777Ｅ-mail: johnfoo57@ outlook.com

Received: March 23, 2017 Accepted: April 27, 2017 Online published: May 2, 2017

doi:10.5296/jpag.v7i2.10992

URL: https://doi.org/10.5296/jpag.v7i2.10992

\begin{abstract}
The present study is designed to propose values for developing civil servants' commitment to share ideas on how to reduce public organization cost and in turn commitment to implement cost reduction policy in the workplace. If civil servants feel that they have a moral obligation in paying back the country through remain with the employing public agencies they become receptive towards cost reduction policy. To instil this moral obligation this study proposes the elements of means, attitude towards leaders and attitude towards government. The researchers have applied cross-sectional survey research to validate the framework. It is found that
\end{abstract}


attitude towards government influenced the development of civil servants' commitment to share knowledge in the workplace significantly. On the other hand, means and attitude towards government influenced the development of civil servants' commitment to implement cost reduction policy in the workplace significantly. The practical implications are the discovery of theoretical, personal, and workplace practical best practices for the establishment of strategies to establish knowledge sharing commitment and cost reduction commitment amongst civil servants in the public organizations.

Keywords: Means, Attitude towards leaders, Attitude towards government, Knowledge sharing commitment, Cost reduction commitment, Public organization

\section{Introduction}

Low deficit rate is one of the determinants of stronger fiscal position of a country (Blanchard, 2011; Othman, Ismail, Syed Ismail, Saidin, Rahim, Md Saleh, Samsudin \& Mohd Lazim, 2007). In order to reduce deficit the government has to increase revenue and reduce expenditure (Blanchard, 2011; Othman et al., 2007). However, due to time constraint and difficulty in getting access to public sector financial data, this study focuses on identifying strategies for reducing expenditure. This is because most of government tax revenue including Malaysia is contributed by corporate tax, which is quite complicated to be studied as global business environment is always fluctuating (Lehar, Anas \& Tey, 2014). On the other hand, reducing expenditure is usually an internal matter of government agencies or departments, which can be monitored and controlled by the top management. Thus studying the implementation of cost reduction policy in the public sector is much more feasible and practical.

However, reducing expenditure is not a favoured option for a populace government. This is because people expect high quality of service and good living environment (high income and low cost of living) from the government. If the people are not happy with the current government, the ruling party might lose the election and in turn power to rule the country. Keep spending money for pleasing people, however, might worsen national fiscal deficit and in turn prospect for economic growth. The best example of country that faces this dilemma is Greece, which is still struggling to settle their debts and facing risk to be expelled from the Euro Zone. To reduce fiscal deficit and in the meantime maintain political stability in the country Selamat, Mat Saat, Murad and Foo (2017) argued that the government can implement low-cost yet high-impact public services. However, civil servants must firstly have commitment to determine strategies to implement low-cost yet high-impact public services (Selamat et al., 2017).

This study argues that to increase civil servants' commitment to share ideas on strategies to implement low-cost yet high-impact public services and in turn commitment to implement cost reduction policy in the workplace, they must have a moral obligation in paying back the organization through remain with the employing organization. This is coined as normative commitment (Meyer \& Allen, 1991). In short, the objective of this study is to examine values that can develop positive social experiences amongst civil servants so that they become more willing to remain with the employing public agencies and in turn share knowledge or ideas on 
what is the best strategy to reduce public organization operational cost. To assist in developing positive social experiences this study argues that civil servants must be equipped with positive understanding on means, attitude towards leaders and attitude towards government. Thus all these values are embedded in this research conceptual framework.

The paper is organized as follows. Next section presents a theoretical justification for every element in the conceptual framework. Section 3 discusses research approach adopted to validate the proposed factors. Finally, a conclusion is presented in the concluding section.

\section{Theoretical Overview}

For the theoretical understanding of public organization cost reduction we posit that public organization cost reduction is based on the concepts of individual commitment and knowledge sharing. In the following sections a discussion of individual commitment and knowledge sharing is offered.

\subsection{Public Sector Financial Management}

The most important activity in public sector financial management is budgeting. There are three types of government budget, namely, deficit budget, surplus budget and balanced budget. Amongst the three types of government budget, deficit budget is the one that is usually creating negative perception amongst credit rating agencies, business community and people (Alessi, 2012; Blanchard, 2011). This is because it shows government incapability in controlling expenditures and increasing revenues. The failure to increase revenues is also related to the failure to create business activities through public projects such as infrastructure, highway, hospital, school and others. Thus managing deficit rate for the sake of economic growth is critical to every country including Malaysia.

Due to negative impact of high deficit rate on the financial system and fiscal strength, a country that has high deficit rate is usually given low rating by the credit rating agencies such as Standard \& Poor, Moody's, and Fitch Group (Alessi, 2012). The country that get poor rating will be imposed higher interest rate by the international financial institutions including companies incorporated in that country. This will affect badly domestic direct investment in the country (Lehar et al., 2014; Blanchard, 2011). Foreign direct investment will be also badly affected because foreign investors are reluctant to invest in a country that is not financially and politically stable (Lehar et al., 2014; Blanchard, 2011). Low investment will reduce economic growth and in turn increase unemployment rate in the country (Lehar et al., 2014; Blanchard, 2011). This is the scenario that every government in the world, including Malaysia, is trying to avoid. Thus obtaining good ratings through balanced budget or lower deficit rate is a must for every country.

There are two ways of reducing budget deficit which are increasing revenue and reducing expenditure (Blanchard, 2011; Othman et al., 2007). However, the focus of this research is on reducing expenditure. As $80 \%$ of Malaysian tax revenues contributed by corporate tax, the area of increasing revenue is quite complicated as it is depending on global economy, which is always fluctuating (Lehar et al., 2014). Cost reduction is normally an internal matter of ministries, departments and agencies, which can be monitored and controlled by the 
government (Othman et al., 2007). Thus the study on this phenomenon is much more feasible and practical and in tandem with the aspiration of many governments in the world.

\subsection{Public Organization Cost Reduction and Tacit Knowledge}

Usually, the reduction of government expenditure is looked at the organizational perspective. In this case, the ministries, departments and agencies have to cut several non-critical expenses and postpone non-critical projects. This study, however, will look at the individual perspective because it is quite difficult to get access data on public expenditure from the organizational perspective. The individual perspective that this study intends to investigate is civil servants' commitment to share ideas on what is the best strategy to implement low-cost yet high-impact public services and in turn commitment to implement cost reduction policy in the workplace.

The need for civil servants' commitment in identifying strategies to reduce public organization operational cost is critical due to the ideas for those strategies exist in tacit forms (tacit knowledge). The ideas are developed from civil servants' learning process (formal and informal) and this learning occurs in an individual's mindset (Beveren, 2002; Churchman, 1971). As the ideas reside in civil servants' brain, they inherit the characteristics of tacit knowledge which are highly personal, difficult to externalize and difficult to share (Henttonen, Kianto \& Ritala, 2016; Amayah, 2013; Selamat \& Choudrie, 2007; Tsoukas, 2002; Nonaka \& Takeuchi, 1995).

Selamat, Selladurai and Abdul Halim (2015), Selamat and Choudrie (2007), Selamat (2005) and Haldin-Herrgard (2000) stated that there are four factors that lead to the difficulty in expressing and sharing tacit knowledge, namely, perception, language, time, value and distance. In the case of perception, the characteristics of unconsciousness result in the people become unaware of the full range of their knowledge and potential (Polanyi, 1967). The difficulty with language is related to the characteristic of tacit knowledge, which exists in a non-verbal form (Haldin-Herrgard, 2000). Time also becomes a hurdle in the process of externalizing and sharing of tacit knowledge. This is because, during the formation of knowledge in the mindset, tacit knowledge internalization needs a longer period of time. The difficulty in value results from the nature of tacit knowledge whereby not all knowledge that resides in an individual's mindset have value that give them merit to be externalized and shared (Haldin-Herrgard, 2000). Distance factor also contributes towards the difficulty in tacit knowledge externalization and sharing. This is because tacit knowledge can be externalized and shared actively if the involved individuals meet each other and then having face-to-face interaction (Selamat \& Choudrie, 2007; Selamat, 2005; Holtshouse, 1998; Leonard-Barton \& Sensiper, 1998).

Other inhibitors that could stop civil servants from sharing ideas on what is the best strategy to reduce expenditure are such as fear, low confidence level, reluctance to do it, and confusion due to negative sentiments (Henttonen et al., 2016; Amayah, 2013). This phenomenon occurs in an organization due to the difference in superiority and seniority. Another factor that separate civil servants in the workplace is different nature of social background (Amayah, 2013). This is due to the nature of human beings being attracted to a 
group that has similar backgrounds such as academic qualification, age, race, gender and others (Henttonen et al., 2016; Amayah, 2013; Ali, 1998).

Another possible factor that could discourage communication between civil servants is the acceptance of others towards their ideas (Amayah, 2013; Selamat \& Choudrie, 2007; Bennett, 1998). Some civil servants feel that their opinions will not be accepted due to their positions within the organization or that they do not have enough of an influence to provide a significant contribution to the organization (Amayah, 2013; Selamat \& Choudrie, 2007; Bennett, 1998). This apprehension forces them to keep their knowledge or skills in their own mindset and results in the individuals becoming passive in formal meetings and undertaking sole tasks.

To recapitulate it could be argued that the success of public organization cost reduction depends on civil servants' commitment to implement it. They must participate in the process of analyzing others' ideas and examining the feasibility of their ideas in the practical setting during the meeting actively. This involves the process of externalizing and sharing of tacit knowledge in the workplace. Eventually, they will make a consensus on what is the most applicable strategy to reduce operational costs in their organization. Ignoring the critical role of civil servants commitment in the workplace could lead to the creation of passive civil servants and in turn the inefficiencies in determining strategies for reducing public organization operational cost (Selamat et al., 2017; Saint-Onge, 1996). Thus understanding values that can develop civil servants' commitment to share ideas on strategies to reduce expenditure and in turn commitment to implement cost reduction policy is paramount. To face such phenomenon, this research argues that civil servants need to be equipped with positive values of means, attitude towards leaders and attitude towards government. Being equipped with these values enables civil servants to have a moral obligation in paying back the organization through remain with the employing organization and in turn participate in knowledge sharing actively in the workplace. Civil servants who are not embedded with these values tend to be passive in terms of commitment to share knowledge or ideas on what is the best strategy to reduce expenditure and commitment to implement cost reduction policy.

\subsection{Developing Civil Servants' Commitment}

As stated above, this study intends to propose values that can increase civil servants' commitment to share ideas on strategies to reduce expenditure and in turn commitment to implement cost reduction policy. The focus of this research is on what values that can develop civil servants' self-commitment (individual commitment) and not what public organization should do to increase civil servants' commitment in public organization cost reduction (organizational commitment). This research proposes three values that could develop civil servants' commitment to share knowledge or ideas on what is the best strategy to reduce expenditure and in turn participate in cost reduction policy implementation, which are means, attitude towards leaders and attitude towards government.

\subsubsection{Means}

In the organizations, means refers to standard operating procedure or organizational best 
practice (Selamat et al., 2017; Selamat et al., 2015; Selamat \& Choudrie, 2007). Standard operating procedure or organizational best practice can be described as "meta-competencies" which allows staff members to create and adapt specific competencies for specific situations (Burgoyne, 1988). By adopting standard operating procedure, staff members can undertake tasks based upon "the right approach for the right situation." This enables organizations implementing economical approach when undertaking daily operation without compromising on product or service quality.

Undertaking tasks in accordance with the standard operating procedure enables cost, time and energy savings (Selamat et al., 2015; Abdul Wahab, Selamat, \& Saad, 2013; Selamat \& Choudrie, 2007). Thus, to reduce public organization operational costs, civil servants must know the correct way of handling tasks in the workplace. This highlights the importance of staff training programs in the public organization (Armstrong-Stassen, 2008; Kooij, de Lange, Jansen \& Dikkers, 2008; McEvoy \& Blahna, 2001; Maurer \& Rafuse, 2001). Training on public sector financial management could also be offered to ensure that civil servants understand the rationale of cost reduction policy. In short, means in this research refers to understanding on working procedure and public sector financial management. Good understanding on working procedure enables civil servants to suggest which tasks that can be simplified, reduced, automated and/or eliminated. Additionally, an in-depth understanding on public sector financial management increases civil servants' awareness on the importance of achieving balanced budget and in turn motivates them to share ideas during the process of identifying strategies to reduce public organization operational costs.

Armstrong-Stassen (2008), Kooij et al. (2008), McEvoy and Blahna (2001) and Maurer and Rafuse (2001) stated that the opportunity to develop skills and competencies may facilitate workers' commitment because the availability of training is a strong signal that the organization is willing to 'invest' in its workforce. Thus it could be said that extensive training on public sector financial management can improve civil servants' skill and mentality on fiscal strength and its impact on economic growth and in turn develop commitment to share ideas on how to reduce public organization operational costs. Furthermore, cost reduction as a strategy to strengthen fiscal position requires a different skill set that goes beyond budget preparation, and is accompanied by a different mental model (Othman et al., 2007).

From the above discussion it could be argued that every civil servant must know working procedure and public sector financial management in depth before cost reduction policy could be practiced extensively in the organization. This is to ensure right action is taken at the right time. Thus the element of means needs to be emphasized when establishing commitment to share ideas on strategies to reduce public organization operational costs and in turn commitment to implement cost reduction policy. In short, it could be said that there is a potential relationship between means, commitment to share ideas on strategies to reduce public organization operational costs and commitment to implement cost reduction policy. Thus the following hypotheses are proposed:

H1a: There is a relationship between means and cost reduction commitment amongst civil servants 
H1b: There is a relationship between means and knowledge sharing commitment amongst civil servants

H1c: The relationship between means and cost reduction commitment is mediated by knowledge sharing commitment amongst civil servants

\subsubsection{Attitude towards Leaders}

Fishbein and Ajben (1975) state that attitudes are learned disposition to respond to an object or behaviour. It is representing a hierarchy of effect from feeling or judgments toward person, object or issue and linked to user behaviour (McMillan, Hwang \& Lee, 2003). There are three components of attitudes, namely, cognitive, affective or behavioural responses (Min \& Lee, 2009; Simon \& Peppas, 2004). Attitude is the most important concept that is used to explain user behaviour. This is evident from many studies that used it as one of the determinants in explaining user behaviour (Jahng, Jain \& Ramamurthy, 2007; Simon \& Peppas, 2004; McMillan et al., 2003; Fishbein \& Ajben, 1975). For example, in the area of marketing, the concept of attitude has been used to understand the effectiveness of advertisement (Simon \& Peppas, 2004; McMillan et al., 2003). In the online world, the concept of attitude has been linked with website acceptance whereby online user predisposition to respond favourably or unfavourably to a website, especially with the enormous growth of e-commerce, has been measured (Chen, Clifford, \& Wells, 2002).

Hwang, Yoon and Park (2011) stated that it is important to understand users' attitudes because it can generally predict their purchasing intention and behaviour. For example, the users have stronger intention to purchase online product when they react favourably to an advertisement about that product. This logic has been proven with respect to attitude towards a website (Bruner \& Kumar, 2005).

Jain and Jeppesen (2013) found significant relationship between management cognitive styles and knowledge management practices in public organizations. Yao, Kam and Chan (2007) supported this by saying that senior management in the public administration sector should be made more aware of what knowledge management can do to help improve organizational efficiency and effectiveness. Rhodes, Biondi, Gomes, Melo, Ohemeng, Perez-Lopez, Rossi and Sutiyono (2013), when comparing the performance of public sector in Brazil, Italy, Portugal, Spain, Ghana, Indonesia and Ireland, found that administrative culture and the attitudes of elites are critical determinants of public sector performance.

From the above findings it is argued that civil servants' actions can be strongly influenced by their attitude towards leaders in the workplace. Positive attitude towards leaders make them more receptive to public organization cost reduction and vice versa. This axiom leads to the pre-supposition that attitude towards leader influences civil servants' commitment to share ideas on strategies to reduce public organization operational costs and commitment to implement cost reduction policy. All these scenarios lead to the following hypotheses:

H2a: There is a relationship between attitude towards leaders and cost reduction commitment amongst civil servants

$\mathrm{H} 2 \mathrm{~b}$ : There is a relationship between attitude towards leaders and knowledge sharing 
commitment amongst civil servants

$\mathrm{H} 2 \mathrm{c}$ : The relationship between attitude towards leaders and cost reduction commitment is mediated by knowledge sharing commitment amongst civil servants

\subsubsection{Attitude towards Government}

Another attitude that is studied in this research is attitude towards government. Recent political turmoil in Thailand shows a potential role of attitude towards government on knowledge sharing commitment and public organization cost reduction commitment. Many civil servants in Thailand joined the protestors in a rally to oust the then Thailand Prime Minister Yingluck Shinawatra. They dare to leave the office and postpone all the works. The most critical impact of the turmoil is that Thailand's economic growth slowed significantly in the final quarter of 2013 and the state planning agency cut its forecast for this year because of political unrest that could prevent the formation of a fully functioning government for months (Reuters, February 17, 2014). Southeast Asia's second-biggest economy after Indonesia grew a seasonally adjusted 0.6 percent in October-December from the previous three months. That was well down on July-September's freshly-revised 1.4 percent pace. For full-year 2013, the growth was 2.9 percent, far below the 6.5 percent in 2012 when Thailand was rebounding from devastating floods the preceding year.

As a democratic country like Thailand, the above scenario could also happen in Malaysia. Under the democratic system, the government is elected by the people and civil servants also involve in the election process. As a result, they incline to favour one political party rather than the others. If the ruling party is not the one that they vote, civil servants incline to spend most of the time in the office condemning ruling government and having debate with those who favour the ruling government. This phenomenon is not healthy and if not controlled could lead to lower productivity (Rhodes et al., 2013).

The above scenario highlights that attitude towards government could influence civil servants willingness to collaborate and cooperate at the workplace. This leads the involved public organizations to operate ineffectively and inefficiently. In short, it could be said that negative attitude towards government will discourage civil servants from sharing ideas on strategies to reduce public organization operational costs and implementing cost reduction policy in the workplace. Thus the following research hypotheses are proposed:

H3a: There is a relationship between attitude towards government and cost reduction commitment amongst civil servants

$\mathrm{H} 3 \mathrm{~b}$ : There is a relationship between attitude towards government and knowledge sharing commitment amongst civil servants

$\mathrm{H} 3 \mathrm{c}$ : The relationship between attitude towards leaders and cost reduction commitment is mediated by knowledge sharing commitment amongst civil servants

To complement the above hypotheses and in tandem with this research conceptual framework, the following hypothesis is proposed as the final hypothesis:

H4: There is a relationship between knowledge sharing commitment and cost reduction commitment amongst civil servants 


\section{Research Methodology}

Data of this study were gathered through a survey approach. Survey is considered to be the favoured tool for data collection amongst quantitative researchers (Fowler, 2009). In addition, it is one of the most common data collection methods for examining the participation in cost reduction commitment and knowledge sharing commitment (Selamat et al., 2015; Jain \& Jeppesen, 2013; Amayah, 2013). Survey research suits the unit of analysis of this study, which are civil servants in the Malaysian public organizations. Dwivedi (2005) suggested that when the unit of analysis is individual rather than organization, survey approach is more preferable than other approaches such as case study. This study utilized stratified random sampling as a sampling technique. Stratified random sampling, as its name implies, involves a process of stratification or segregation, followed by random selection of subjects from each stratum (ministries) (Sekaran, 2003; Fowler, 2009; Babin \& Griffin, 2010). A total of 400 civil servants in federal government ministries across Malaysia were randomly selected. The questionnaires were distributed by liaison officers (most of them are auditors of the Auditor's General Department). They were selected because they have the authority to communicate with the respondents. Multiple regression analysis was used to test the relationship between independent variables and dependent variable.

\section{Research Findings}

Out of 400 distributed questionnaires, 130 were returned. This resulted in a response rate of $32.5 \%$. As suggested by Sekaran (2003), a response rate of $30 \%$ is considered adequate for mail survey research. Based on this suggestion, the response rate of this study $(32.5 \%)$ was above the recommended rate. In turn, the findings of this research can be generalized to the population.

\subsection{Profile of Respondents}

The frequency and percentage of each demographic profile are illustrated in Table 1. The reported demographic profiles include gender, age and number of years working in the current public agency.

Table 1. Background of the respondents $(\mathrm{N}=130)$

\begin{tabular}{lcc}
\hline & Frequency & Percentage \\
\hline Gender & 56 & \\
Male & 74 & 43.1 \\
Female & 56.9 \\
\hline Age (years) & 5 & \\
$21-30$ & 59 & 3.8 \\
$31-40$ & 40 & 45.4 \\
$41-50$ & 26 & 30.8 \\
$51-60$ & - & 20.0 \\
$>60$ & & - \\
\hline Length of Service & 30 & 23.1 \\
$<5$ & 40 & 30.8 \\
$<10$ & 16 & 12.3 \\
$<15$ & 20 & 15.4 \\
$<20$ & 24 & 18.5 \\
$>21$ & & \\
\hline
\end{tabular}


In this research, gender distribution was slightly higher for female. Out of 130 respondents, $56(43.1 \%)$ respondents are male and $74(56.9 \%)$ respondents are female. The largest group of respondents $(\mathrm{N}=59,45.4 \%)$ reported that they were in the "31-40" age group. The second largest group consisted of respondents with age "41-50" ( $\mathrm{N}=40,30.8 \%)$, third largest group consisted of respondents with age "51-60" $(\mathrm{N}=26,20.0 \%)$ and fourth largest group consisted of respondents with age " $21-30$ " $(\mathrm{N}=5,3.8 \%)$. There was no respondent in "Over 60" age group.

The largest group of respondents $(\mathrm{N}=40,30.8 \%)$ indicated that they have worked at the current public agency "10 years or less". The second largest group of respondents $(\mathrm{N}=30$, $23.1 \%$ ) reported that they have worked at the current public agency "5 years or less". This is followed by "over 21 years" category $(\mathrm{N}=24,18.5 \%)$.

\subsection{Reliability Analysis}

To test the reliability of the research instrument, as suggested by Sekaran (2003), this study utilized internal consistency method which is measured by Cronbach's alpha. The coefficient for the Cronbach's alpha is expressed between 0 and 1.00. The results of the Cronbach's alpha values of the variables are as illustrated in Table 2.

Table 2. Reliability coefficients for variables $(\mathrm{N}=130)$

\begin{tabular}{lcc}
\hline Variable & N of Item & Cronbach's Alpha \\
\hline Means & 5 & 0.934 \\
Attitude towards Leaders & 6 & 0.838 \\
Attitude towards Government & 6 & 0.812 \\
Knowledge Sharing Commitment & 6 & 0.775 \\
Cost Reduction Commitment & 6 & 0.895 \\
\hline
\end{tabular}

As shown in Table 2, the Cronbach's alpha values for variables varied between 0.775 (knowledge sharing commitment) and 0.934 (means). One variable possessed Cronbach's alpha values above 0.90 (means), three between 0.80 and 0.90 (attitude towards leaders, attitude towards government and cost reduction commitment), and one between 0.70 and 0.80 (knowledge sharing commitment). In other words, none of the study variables demonstrated below the minimum reliability level of 0.60 (Hair, Black, Babin, Anderson, \& Tatham, 2006). Thus the internal consistency of the measures used in this study was considered acceptable (Churchill, 1979; Sekaran, 2003).

\subsection{Multiple Regression Analysis}

Data refinement was undertaken prior to multiple regression analysis. It was divided into data screening and data testing, which aim to fulfill the multivariate assumptions (Hair et al., 2006). Data screening consists of three tests which are missing data, response bias and outliers identification. On the other hand, data testing consists of linearity, normality, homoscedasticity and multicollinearity tests. The criteria for all these tests were met in this study. 


\subsubsection{Effect of Independent Variables on Cost Reduction Commitment}

To test the effect of independent variables on cost reduction commitment multiple regression analysis was utilized and its findings are illustrated in Table 3. As illustrated in Table 3, the value of adjusted $\mathrm{R}$ square is 0.304 . This shows that all independent variables (means, attitude towards leaders and attitude towards government) explain $30.4 \%$ variance in civil servants' commitment to participate in cost reduction policy implementation.

Table 3. Effect of independent variables on cost reduction commitment

\begin{tabular}{lccc}
\hline & B & t & Sig. \\
\hline Means & .288 & 3.422 & .001 \\
Attitude towards Leaders & -.138 & -1.456 & .148 \\
Attitude towards Government & .547 & 4.968 & .000 \\
$\mathrm{R}^{2}$ & 0.304 & & \\
F & 18.334 & & \\
Sig. & 0.000 & & \\
\hline
\end{tabular}

Table 3 also illustrates that only two variables were found to have significant effect on commitment to participate in cost reduction policy implementation amongst civil servants. They were means $(\mathrm{B}=0.288, \mathrm{t}=3.422, \mathrm{p}<0.01)$ and attitude towards government $(\mathrm{B}=0.547$, $\mathrm{t}=4.968, \mathrm{p}<0.05)$. Thus $\mathrm{H} 1 \mathrm{a}$ and $\mathrm{H} 3 \mathrm{a}$ were accepted and $\mathrm{H} 2 \mathrm{a}$ was rejected.

\subsubsection{Effect of Independent Variables on Knowledge Sharing Commitment}

The results of multiple regression analysis in relation to the effect of independent variables on knowledge sharing commitment are illustrated in Table 4. As illustrated in Table 4, the value of adjusted $\mathrm{R}$ square is 0.661 . This shows that all independent variables (means, attitude towards leaders and attitude towards government) explain $66.1 \%$ variance in civil servants' commitment to share ideas on what is the strategy to reduce operational cost of public agencies.

Table 4. Effect of independent variables on knowledge sharing commitment

\begin{tabular}{lccc}
\hline & B & t & Sig. \\
\hline Means & .030 & .385 & .701 \\
Attitude towards Leaders & -.089 & -1.312 & .192 \\
Attitude towards Government & .407 & 5.085 & .000 \\
$\mathrm{R}^{2}$ & 0.661 & & \\
$\mathrm{~F}$ & 23.199 & & \\
Sig. & 0.000 & & \\
\hline
\end{tabular}

It can also be seen that only attitude towards government $(B=0.407, t=5.085, p<0.05)$ has significant effect on civil servants' commitment to share ideas on strategies to reduce public organization operational costs. Thus $\mathrm{H} 3 \mathrm{~b}$ was accepted and $\mathrm{H} 1 \mathrm{~b}$ and $\mathrm{H} 2 \mathrm{~b}$ were rejected. 
4.3.3 Mediating Effect of Knowledge Sharing Commitment on the Relationship between Independent Variables and Cost Reduction Commitment

Two steps hierarchical regression was carried out to examine the effect of knowledge sharing commitment on the relationship between independent variables and cost reduction commitment (refer Table 5). Model 1 examined relationship between independent variables (means, attitude towards leaders, and attitude towards government) and cost reduction commitment. Model 2 examined the effect of independent variables on cost reduction commitment with the present of knowledge sharing commitment as the mediating variable. Model 1 explained 65.6 percent of variance $\left(\mathrm{R}^{2}=0.656, \mathrm{~F}=22.706, \mathrm{p}<0.01\right)$. Only means $(B=0.184, t=2.244, p<0.05)$ has significant effect on cost reduction commitment.

Table 5. Mediating Effect of Knowledge Sharing Commitment on the Relationship between Independent Variables and Cost Reduction Commitment

\begin{tabular}{lcccc}
\hline & \multicolumn{2}{c}{ Model 1 } & \multicolumn{2}{c}{ Model 2 } \\
\cline { 2 - 5 } & B & $\mathbf{t}$ & $\mathbf{B}$ & $\mathbf{t}$ \\
\hline Means & .184 & $2.244^{* *}$ & .093 & $2.368^{* *}$ \\
Attitude towards Leaders & -.083 & -.978 & -.076 & -1.077 \\
Attitude towards Government & .056 & .953 & .097 & .539 \\
Knowledge Sharing Commitment & & & .162 & $1.835^{*}$ \\
$\mathrm{R}^{2}$ & 0.656 & & 0.666 & \\
$\mathrm{~F}$ & 22.706 & & 21.358 & \\
Sig. & 0.000 & & 0.000 & \\
\hline
\end{tabular}

Notes: $* * * \mathrm{p}<0.01 ; * * \mathrm{p}<0.05,{ }^{*} \mathrm{p}<0.1$

Next, Model 2 indicates that the present of knowledge sharing commitment only increase the $\mathrm{R}^{2}$ to 66.6 percent $\left(\mathrm{R}^{2}=0.666, \mathrm{~F}=21.358, \mathrm{p}<0.01\right)$. The findings also revealed that there were also significant relationship between knowledge sharing commitment and cost reduction commitment $(\mathrm{B}=0.162, \mathrm{t}=-1.835, \mathrm{p}<0.01)$. Additionally, the present of knowledge sharing commitment only decreases the coefficient of means $(B=0.093, t=2.368, p<0.05)$. In other words it can be said that knowledge sharing commitment only mediated the relationship between means and cost reduction commitment (supported $\mathrm{H} 1 \mathrm{c}$ but rejected $\mathrm{H} 2 \mathrm{c}$ and $\mathrm{H} 3 \mathrm{c}$ ). Thus the proposed mediating role of knowledge sharing commitment on the relationship between independent variables and cost reduction commitment was partially substantiated in the practical setting.

\subsection{Discussion}

This study found that means was positively and significantly influenced civil servants' commitment to participate in cost reduction policy implementation but not commitment to share knowledge or ideas on what is the best strategy to reduce office expenditure. This finding is consistent with the previous studies whereby the understanding on organizational best practices develops civil servants' internal strength to bring success to their organizations (Selamat et al., 2015; Abdul Wahab et al., 2013; Jain \& Jeppesen, 2013; Amayah, 2013). 
From this result it could be said that civil servants that do not know how to provide low-cost yet high-impact public services will not participate in cost reduction policy implementation. The probable reason behind this scenario is that cost reduction policy implementation requires a different skill set that goes beyond daily tasks of civil servants and is accompanied by a different mental model. Thus adequate training on public sector financial management must be provided to civil servants so that they could participate actively in cost reduction policy implementation.

This study also found that attitude towards government was positively and significantly influenced civil servants' commitment to share knowledge or ideas on what is the best strategy to reduce office expenditure and commitment to participate in cost reduction policy implementation. This finding is consistent with the previous studies such as Selamat et al. (2017) and Selamat et al. (2015). In other words, attitude towards government was perceived by civil servants as a determinant to participate or not to participate in the discussion on cost reduction policy implementation. The probable explanation could be the norm that attitude towards government is the most important value in every civil servant and reducing expenditure is not exceptional. This is because, based on the norm of reciprocity, when government is good and can be trusted civil servants may feel obligated to reciprocate and become more committed to organizational plans and goals.

Surprisingly, this study found that attitude towards leaders was not positively and significantly influenced civil servants' commitment to share knowledge or ideas on what is the best strategy to reduce office expenditure and commitment to participate in cost reduction policy implementation. Implicit in this finding is that civil servants do not perceive management as an important factor in cost reduction policy implementation. This scenario might be influenced by civil servants' awareness to work professionally whereby they must implement any policies that are implemented by the current management. They should not let political preference influence their performance and responsibility in the workplace.

Last but not least, mediating role of knowledge sharing commitment cannot be obtained in the practical setting. Possible explanation for this scenario is that organizational incentives are considered as the main driver by civil servants in deciding whether to participate or not in cost reduction policy implementation. Nevertheless, this study uncovered that knowledge sharing commitment partially mediated the relationship between means and cost reduction commitment. Implicit in this finding is that training on public sector financial management (means) should be given utmost priority in the process of developing civil servants' commitment to share ideas on strategies to reduce public organization operational costs and commitment to participate in cost reduction policy implementation.

\section{Conclusion}

The objective of this study was to determine whether the values of means, attitude towards leaders and attitude towards government develop civil servants' commitment to share knowledge or ideas on what is the best strategy to reduce office expenditure and in turn commitment to participate in cost reduction policy implementation. From the findings, the proposed conceptual framework was partly validated. The findings showed that the effect of 
means and attitude towards government on civil servants' commitment to participate in cost reduction policy implementation were significant. On the other hand, the effect of attitude towards government on the commitment to share knowledge or ideas on what is the best strategy to reduce office expenditure was significant. Lastly, this study uncovered that knowledge sharing commitment partially mediated the relationship between means and cost reduction commitment.

Although this study have contributed to public financial management area, several limitations have to be considered. First, the context of this study is limited to civil servants. For future research it is suggested that a comparison is made between civil servants and practitioners. Second, this research conceptual framework was tested and examined from the Malaysian perspective. Thus obtaining feedback from the public sector in other countries is necessary. Third, this research adopted cross-sectional survey for data collection. To gain a broad view on the issues related to public organization cost reduction and knowledge sharing, a longitudinal study is advised. Last but not least, unit of analysis of this study was an individual whereby civil servants were selected as the respondents. To gain more variance in the analysis, obtaining feedback from top management in the public agencies is strongly recommended.

\section{Acknowledgement}

The research is financed by SEGi University.

\section{References}

Abdul Wahab, M. S., Selamat, M. H., \& Saad, R. A. J. (2013). The importance of continuing professional education activities amongstMalaysian accountants in public accounting firms. Paper presented at the fourteenth Asian Academic Accounting Association, Penang.

Alessi, C. (2012). The Credit Rating Controversy. New York: Council on Foreign Relations.

Amayah, A. T. (2013). Determinants of knowledge sharing in a public sector organization. Journal of Knowledge Management, 17(3), 454-471. http://dx.doi.org/10.1108/JKM-11-2012-0369

Armstrong-Stassen, M. (2008). Organisational practices and post-retirement employment experience of older workers. Human Resource Management Journal, 18, 36-53.

Babin, Z., \& Griffin, C. (2010). Business research method (8th ed.). Ohio: South-Western/Cengage Learning.

Bennett, R. H. (1998). The importance of tacit knowledge in strategic deliberations and decisions. Management Decision, 36(9), 589-597.

Beveren, J.V. (2002). A model of knowledge acquisition that refocuses knowledge management. Journal of Knowledge Management, 6(1), 18-22.

Blanchard, O. (2011). Macroeconomics (5th ed.). New York: Pearson.

Bruner II, G. C., \& Kumar, A. (2005). Applying T.A.M. to consumer usage of handheld 
Internet devices. Journal of Business Research, 58, 553-558.

Burgoyne, J. (1988). Competency approaches to management development. Paper presented at the IMP conference, Harrogate.

Chen, Q., Clifford, S. J., \& Wells, W. D. (2002, April). Attitude toward the site 11: New information. Journal of Advertising Research, 33-45.

Churchill, G. A. (1979). A paradigm for developing better measures of marketing constructs. Journal of Marketing Research, 16(1), 64-73.

Churchman, C. W. (1971). The design of inquiring systems. New York: Basic Books.

Dwivedi, Y. K. (2005). Adoption, usage and impact of broadband: UK households (Unpublished doctoral dissertation). Brunel University, UK.

Fishbein, M., \& Ajzen, I. (1975). Belief, attitude, intention and behavior: An introduction to theory and research. New York: Addison-Wesley.

Fowler, F. J. Jr. (2009). Survey research method. London: Sage Publications.

Hair, J. F., Black, W. C., Babin, B. J., Anderson, R. E., \& Tatham, R. L. (2006). Multivariate data analysis (6th ed.). New Jersey: Pearson International Edition.

Haldin-Herrgard, T. (2000). Difficulties in diffusion of tacit knowledge in organisations. Journal of Intellectual Capital, 1(4), 357-365.

Henttonen, K., Kianto, A., \& Ritala, P. (2016). Knowledge sharing and individual work performance: an empirical study of a public sector organization. Journal of Knowledge Management, 20(4), 749-768. http://dx.doi.org/10.1108/JKM-10-2015-0414

Holtshouse, D. (1998). Knowledge research issues. California Management Review, 40(3), 277-280.

Hwang, J., Yoon, Y.-S., \& Park, N.-H. (2011). Structural effects of cognitive and affective reponses to web advertisements, website and brand attitudes, and purchase intentions: The case of casual-dining restaurants. International Journal of Hospitality Management, 30(4), 897-907.

Jahng, J., Jain, H., \& Ramamurthy, K. (2007). Effects of interaction richness on consumer attitudes and behavioral intentions in e-commerce: some experimental results. European Journal of Information Systems, 16, 254-269.

Jain, A. K., \& Jeppesen, H. J. (2013). Knowledge management practices in a public sector organisation: the role of leaders' cognitive styles. Journal of Knowledge Management, 17(3), 347-362.

Kooij, D., de Lange, A., Jansen, P., \& Dikkers, J. (2008). Older workers' motivation to continue to work: five meanings of age. A conceptual review. Journal of Managerial Psychology, 23(4), 364-394. 


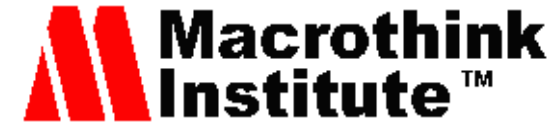

Journal of Public Administration and Governance ISSN 2161-7104

Lehar, H., Anas, Y., \& Tey, H. C. (2014). Malaysian Economy. Kuala Lumpur: Oxford University Press.

Leonard-Barton, D., \& Sensiper, S. (1998). The role of tacit knowledge in group innovation. California Management Review, 40(3), 112-132.

Maurer, T. J., \& Rafuse, N. E. (2001). Learning, not litigating: Managing employee development and avoiding claims of age discrimination. The Academy of Management Executive, 15(4), 110-121.

McEvoy, G. M., \& Blahna, M. J. (2001). Engagement or disengagement? Older workers and the looming labor shortage. Business Horizons, 44(5), 46-52.

McMillan, S. J., Hwang, J., \& Lee, G. (2003). Effects of structural and perceptual factors on attitudes toward the website. Journal of Advertising Research, 43(4), 400-409.

Meyer, J. P., \& Allen, N. J. (1991). A three-component conceptualization of organizational commitment. Human Resource Management Review, 1(61). https://dx.doi.org/10.1016/1053-4822(91)90011-z

Min, J. Y., \& Lee, H. (2009). Getting emotional with the system that mirrors you: Cognitive and affective attitudes towards identity-reflecting information systems. In PACIS. Hyderabad, India. Retrieved from http://aisel.aisnet.org/pacis2009/50

Nonaka, I., \& Takeuchi, H. (1995). The knowledge creating company. New York: Oxford University Press.

Othman, O., Ismail, M. S., Syed Ismail, S. S., Saidin, S. Z., Rahim, M. S., Md Saleh, M. S., Samsudin, R. S., \& Mohd Lazim, M. (2007). Public Sector Accounting in Malaysia (1st ed.). Singapore: Cengage Learning Asia.

Polanyi, M. (1967). The tacit dimension. New York: Doubleday.

Rhodes, M. L., Biondi, L., Gomes, R., Melo, A. I., Ohemeng, F., Perez-Lopez, G., Rossi, A., \& Sutiyono, W. (2013). Current state of public sector performance management in seven selected countries. International Journal of Productivity and Performance Management, 61(3), 235-271.

Saint-Onge, H. (1996, March-April). Tacit knowledge: The key to the strategic alignment of intellectual capital. Strategy and Leadership Journal, 24(2), 10-14.

Sekaran, U. (2003). Research method for business: A skill building approach (4th ed.). Danvers, MA: John Wiley \& Sons.

Selamat, M. H. (2005). Developing Individuals for Developing Learning-Based Systems (Unpublished doctoral dissertation). Brunel University, UK.

Selamat, M. H., \& Choudrie, J. (2007). Using meta-abilities and tacit knowledge for developing learning based systems: A case study approach. The Learning Organization, 14(4), 321-344. 


\section{Macrothink}

Journal of Public Administration and Governance

ISSN 2161-7104 2017, Vol. 7, No. 2

Selamat, M.H., Mat Saat, R., Indra Zuhdi Murat, R., \& Foo, K.S. (2017). Developing civil servants' affective commitment to share knowledge: A case of public organization cost reduction. International Journal of Business and Management, 12(2), 160-170. http://dx.doi.org/10.5539/ijbm.v12n2p160

Selamat, M. H., Selladurai, S., \& Abdul Halim, H. M. (2015). The influence of task accomplishment and attitude on active teaching in Malaysian universities. European Journal of Business and Social Science, 4(1), 35-48.

Simon, S. J., \& Peppas, S. C. (2004). An examination of media richness theory in product web site design: An empirical study. Info, 6(4), 270-281.

Tsoukas, H. (2002). Do we really understand tacit knowledge? Knowledge Economy and Society Seminar, London.

Yao, L. J., Kam, T. H .Y., \& Chan, S. H. (2007). Knowledge sharing in Asian public administration sector: The case of Hong Kong. Journal of Enterprise Information Management, 20(1), 51-69.

\section{Copyright Disclaimer}

Copyright for this article is retained by the author(s), with first publication rights granted to the journal.

This is an open-access article distributed under the terms and conditions of the Creative Commons Attribution license (http://creativecommons.org/licenses/by/4.0/). 